Processing Instruction and Russian: Further Evidence is IN

\author{
William J. Comer, \\ University of Kansas
}

Lynne deBenedette, Brown University 
Processing Instruction and Russian: Further Evidence is IN

Introduction

In their article "The Evidence is IN: Drills are OUT," Wong and VanPatten (2003) argue that there is no evidence from either a theoretical or an empirical standpoint that mechanical drills are necessary for language acquisition, regardless of the language being studied. In place of mechanical drills, Wong and VanPatten posit that focus-on-form instruction, and particularly one of its subsets, Processing Instruction (hereafter PI), can successfully replace mechanical drills in teaching L2 grammar.

Leaver, Rifkin, and Shekhtman (2004) took issue with Wong and VanPatten (2003), raising many objections about the applicability of their conclusions to the teaching of Russian. In Wong and VanPatten's (2004) follow-up to the response, the researchers challenged teachers of Russian to present empirical evidence that mechanical drills (i.e., traditional instruction, hereafter TI) are necessary for language acquisition, or that PI or other focus-on-form approaches would not work for Russian.

The research study presented in this article is an attempt to do precisely that: the study compares the effects of TI and PI for learning a Russian syntactic construction involving directional versus locational expressions. As a syntactic construction, Russian's куда [where to destination] and где [where at - location] distinction represents a similar learning challenge to the French causative faire construction featured in Wong and VanPatten (2003), although the nature of the processing problem is different in the two languages. 
Background

The Evidence for PI

PI is an instructional intervention that seeks to alter certain faulty processing strategies that language learners exhibit, and VanPatten (2004) has formulated and explicated these faulty processing strategies in his theory of Input Processing. The first study to describe the effects of PI versus TI is VanPatten and Cadierno (1993), which targeted learners' interpretation and production of Spanish object pronouns in sentences with SVO and OVS word order. On this grammar point the specific processing problem involved learners' preference for interpreting the first noun of a sentence as the subject or agent, even if this was grammatically impossible. VanPatten and Cadierno's PI treatment had students focus on learning to correctly interpret oral and written input involving Spanish pronouns, while the TI group followed the traditional progression of mechanical, meaningful and communicative drills found in the most popular textbook of Spanish in use at that time. Thus the TI group was focused entirely on producing forms, while the PI group did extensive work on interpretation of forms, including receiving explicit instruction about the processing problem involving the Spanish object pronouns and the First Noun Principle. In the post-test, the PI group exhibited greater improvement than the TI group on the interpretation tasks and made gains similar to the TI group in producing sentences with object pronouns, even though the PI group did not create a single sentence with this form during the treatment. The TI group made no statistically significant improvement in their ability to interpret the targeted form. In their conclusion, the authors argued that PI had a "two for one" effect - in other words, PI's focus on altering learners' faulty processing strategies improves their abilities to interpret input, which then clears the way for production of the targeted forms. 
Since 1993 PI research has expanded to deal with a large number of languages and processing problems beyond the First Noun Principle. Of particular relevance to the current study is the body of PI research that targets the processing problems caused by the Lexical Preference Principle, according to which learners will prefer to derive a sentence's meaning from its lexical items rather than from grammatical forms where the two encode the same information (VanPatten, 2004). For example, in the sentence "Yesterday we talked about politics" the learner is more likely to understand the past time nature of this statement because of the lexical item "yesterday" rather than the past tense marker (-ed) on the verb form "talked." Thus a PI treatment targeting the Lexical Preference Principle will seek to remove lexical hints to sentence interpretation so that learners are pushed to process grammatical information. Cadierno (1995) examined the Spanish preterite tense and temporal adverbs, finding that the PI treatment, which forced students to recognize the time of an action based on verb form rather than temporal adverb, was superior to the TI and control groups on the interpretation task. Both the PI and the TI groups performed significantly better than the control group on the production task, with no significant difference found between the PI and TI groups on the production task. The improvement in interpretation for the PI group and the improvement in production for both PI and TI groups held from immediate post-test through the two delayed post-tests. Benati (2001) conducted a similar study with the future tense in Italian, although he added an oral production task to the aural interpretation and written production tasks. He found that the PI group significantly outperformed the TI group and that the TI group significantly outperformed the control group on the aural interpretation task. The PI and TI groups showed similar improvement on the written and oral production tasks and both were significantly better than the 
control group. The improvements in the PI and TI groups on the three tasks were maintained in the delayed post-test.

Since 2004, Lee and Benati (see Lee and Benati, 2010 for an overview of the PI research studies) have been working to expand the database of PI studies so that it now includes not only English learners of Spanish, French, Italian, and Japanese, but also speakers of other L1s learning English as a second language. Benati (2005) compared PI, TI and Meaning-Based Output Instruction (MOI) groups of Chinese and Greek school-age learners of English as a second language on the issue of the English simple past tense. There again PI groups outperformed both TI and MOI groups on the sentence interpretation task; all three treatment groups improved similarly on production tasks. Lee and Benati (2007a) have compared PI in traditional classroom instruction with computer-based delivery; they have offered evidence for the transfer-of-training and cumulative effects of PI to other structures (Benati and Lee, 2008) and evidence for the effect of PI on learners' output in discourse tasks (Benati and Lee, 2010). In summarizing the various strains of PI research Wong (2010) states: "A striking finding from all strands of PI research is that PI or SIA [structured input activities -authors] are always as effective or better when compared to other instructional treatments" (p. 198 - emphasis of the original).

Nevertheless, PI research is just starting to look at the acquisition of languages that have complex noun phrase morphology, such as Germanic and Slavic languages. Concerning German and the First Noun Principle, Culman, Henry, and VanPatten (2009) have examined PI with and without explicit instruction for teaching the German accusative case to English speakers, and they found that explicit instruction does seem to help learners make better form-meaning connections from the language input. Morton, Yakimova and VanPatten (2011) found similar 
benefit for explicit instruction in the speed at which learners of Russian began to process the animate accusative case endings in SVO and OVS sentences in a PI treatment. Comer and deBenedette (2010) considered the applicability of PI treatments to various issues in Russian grammar, concluding with a brief PI vs. TI study of Russian's directional versus locational expressions. In their preliminary findings both the TI group and the PI group improved between pre-test and post-test, although there was no statistical advantage for one instructional intervention over another in either interpretation or production. This current study reexamines that grammatical point with an expanded and more carefully controlled treatment.

\section{The Processing Problem}

The central syntactic problem examined here is the distinction in Russian between directional expressions (i.e., going to a place) and locational expressions (i.e., being in a place). Both English and Russian can express this distinction by choice of verb (using a motion verb like "go" or a locational verb such as "reside"). English, however, additionally uses the lexical choice of preposition (to versus in/at, for example) to express the distinction. In Russian, since the same two prepositions (в/на) can convey both the locational meanings "in/at" and the directional meanings "into/to," it is the case ending of the place noun that signals the difference between a directional and a locational phrase. Russian uses в/Ha with the accusative case of the place noun to express directionality, while в/на with the prepositional case signals location. From the point of view of the Lexical Preference Principle, this means that learners of Russian are likely to interpret the directionality or locationality of a sentence based on the lexical meaning of the main verb rather than attending to the meaningful, but redundant, grammatical information encoded in the case of the object of the prepositions в/Ha. Thus the PI treatment for 
this syntactic form requires structured input (hereafter SI) that removes lexical hints about direction/location and forces learners to attend to the grammatical expression of that meaning encoded in the choice of case endings.

One challenge in creating Russian SI for a study that requires a number of nouns expressing common place names is the complexity of Russian noun morphology. The case ending on a Russian noun indicates its grammatical function in the sentence; there are six possible cases, thus a noun could theoretically have as many as twelve distinct endings (six singular, six plural). The specific ending required in any given case depends on the gender of the noun (masculine, feminine, neuter) and on the type of final consonant on the noun's stem (hard/unpalatalized, soft/palatalized, glide). These two factors combine to determine the noun's declensional class. For genders and declensional classes, see Table $1 .^{1}$

It is difficult to imagine any communicatively focused language teaching which could restrict the choice of lexical items to those of only one gender and/or declensional class. Thus the diversity of morphological endings in this research is of necessity larger than in other PI vs. TI studies. Nevertheless for the study we restricted lexical items for the pre- and post-tests to singular nouns that fit five declensional classes (see Table 2). The treatment materials were similarly restricted to these classes with a couple of exceptions: the high frequency Russian word for «university classes» is занятия, a neuter plural noun that L2 learners frequently misconstrue as a feminine singular noun belonging to declensional class 6 .

In addition to the fact that the place words belong to different declensional classes, their accusative and prepositional case endings themselves vary by declensional class, and any given ending may be associated with more than one grammatical case. Table 2 summarizes the case 
endings for the five declensional classes targeted in this research. Forms where the prepositional or accusative endings differ from the nominative are underlined.

As the table makes clear, even within this restricted set of declensional classes the endings for a specific case are often not unique. For example, -e is the most common ending for the prepositional singular of masculine, feminine, and neuter nouns with hard stems. However, e is also a nominative and accusative ending for a small class of neuter nouns with a soft stem and a large class of neuter nouns with stems ending in -ий-. То parse a form successfully a Russian speaker needs to connect the encountered word form with its contextual syntactic function (i.e., case) and its declensional class; in other words, successful parsing assumes that learners are aware of the nominative, «dictionary» form of a noun (for example, that the word for «library» is библиотека rather than библиотек ${ }^{2}$ ).

Previous PI research dealing with the Lexical Preference Principle has usually limited itself to a single form-meaning mapping (e.g., teaching the regular third person singular forms of the past tense or future tense) and has primarily examined verbal morphology. The current study expands the extant PI research by focusing on complex noun morphology, where five possible surface forms (Accusative $\varnothing$ ending, Accusative -y, Accusative -ю, Prepositional -e, and Prepositional -и) map to two complementary meanings (destination/location).

\section{Research questions}

1) Will the PI treatment for this topic in Russian show the same «two for one» effects on both interpretation and production as PI has shown in previous studies? That is, for both the interpretation and production tasks, will learners who have had extensive training in interpreting locational and destinational phrases in aural and written input perform better than learners who have had traditional output-focused instruction? 
2) Is there any effect for institutional type on the effectiveness of PI and TI?

3) Is there any difference between treatment types in the patterns of students' accuracy with noun forms from different declensional classes? Are certain noun classes easier for students to learn than others?

\begin{abstract}
Research Design
The design of this study is quasi-experimental using intact groups that were randomly assigned to one of two treatments, with a pre-test and immediate post-test. Due to logistical constraints, no control group was included in this study.
\end{abstract}

\title{
Subjects
}

The subjects come from six intact sections of beginning Russian classes, three enrolled during the Fall 2009 and three enrolled in Fall 2010 semesters. Four sections were enrolled at a large public university (U1), and two sections at a highly selective private university (U2). The average composite ACT score for entering students at the public university in 2009 was 24.8 , while $75 \%$ of students enrolling at the selective private institution scored 29 or higher on the ACT. At each institution half of the sections were assigned to the TI treatment, and half to the PI treatment. From a total population of 80 , two students did not agree to participate in the research; nine students failed to be present for all stages of the research (pre-test, 2-day treatment, post-test). From the remaining pool the researchers excluded five subjects because of knowledge of another Slavic language that has a similar distinction of directionality and location, as well as another four subjects who had a pretest raw score of 13 or higher out of a possible 22 (i.e., $>55 \%$ ). This left 32 participants in the PI treatment ( 22 from the public university and 10 
from the private university), and 28 in the TI treatment (20 from the public university and 8 from the private university). Fifty-eight of these sixty participants reported studying at least one other foreign language before starting Russian, and twenty-four had previously studied two or more languages other than Russian. Fifty-four of the participants claim English as their first language; eight had some prior experience studying Russian, but all of these students were properly placed into a first-year language course. None of the students with previous Russian scored high enough on the pre-test to be eliminated from the study.

Compared with learners in many other PI studies, the participants in this research are unusual in that for all but two of them Russian is at least the second foreign language that they have studied. However, two previous research studies (Benati \& Lee with McNulty, 2010 and Lee \& Benati with Aguilar-Sánchez and McNulty, 2007) have included groups of learners with mixed backgrounds in foreign languages and even native languages, in both cases without compromising the research results. Without a similar compromise as in this study, it may be impossible ever to extend PI research to less commonly taught languages, to which learners rarely come as a first foreign language.

\section{Instructional Context for Study}

Both institutions use the same elementary Russian textbook Nachalo: Book 1 (Lubensky, Ervin, McLellan, and Jarvis, 2001) and had covered through chapter 3 part 2 before the experimental treatment. Thus at the time of the treatment the students had become familiar with the prepositions в/на [in, at, to, on, into, onto] in their locational meanings (in, at, on), as well as the prepositional case endings in the singular to express locations for all of the targeted declensional classes. They were familiar as well with the accusative case endings for all targeted 
declensional classes in its function as direct object of a transitive verb. For this reason, neither treatment needed to teach the morphological endings of either case. The sole new grammatical point presented in the treatment was thus the distinction between directionality and location in prepositional phrases with в/на [in, at, to, on, into, onto].

\section{Pre-test and Post-test}

Both the pre-test and post-test consisted of two tasks. The first was a sentence-interpretation task for which students heard a sentence and had to place a check to show whether the sentence indicated the subject was headed to a destination (going to a place), was in a location (being at a place), or was neither of these (see Appendix A). The block of 24 sentences created for the interpretation task featured 14 nouns, 10 of which occurred in both destinational and locational sentences (a total of 20 sentences); four nouns were in distractor sentences requiring the nominative case. These interpretation sentences were audio recorded by one of the researchers. There was a five second pause after each sentence, and the researcher read the sentences only once. The presentation order of the recorded sentences was scrambled to create an A and B version of the audio recording, each containing 12 sentences. The interpretation task on each test included two distractors, six destinational sentences and four locational sentences. Three groups heard version A on the pre-test and version B on the post-test. Three other groups heard version B on the pre-test and version A on the post-test.

In the pre- and post-test production activity, students had to complete a sentence with a required form of a noun cued in Russian in the nominative case (see Appendix B). Six sentence stems required destinational phrases, and six stems required locational phrases. Three distractor sentences required the nominative case. Vocabulary was glossed, and a picture of each cued 
place word was included so that all students could understand the meaning of every sentence. Twelve nouns were picked for this section and were used to generate 12 destinational and 12 locational sentences. From the total of 24 sentences, six destinational and six locational sentences were used in the pre-test, and the remaining 12 in the post-test. Thus the destinational and locational sentences in the production task on the pre- and post-tests were mirror images of each other: if a noun was in a locational phrase in the pre-test, it was featured in a destinational phrase in the post-test. The three distractor sentences for each version of production task included one masculine, one feminine, and one neuter noun. A random number generator was used to establish the presentation order of the sentences in each part of the pre- and post-tests.

\section{Treatment Materials}

Although the TI materials of VanPatten and Cadierno (1993) included mechanical, meaningful, and communicative drills, for this study the TI materials (see sample in Appendix D) included only mechanical drills, to test the claim made by Wong and VanPatten (2003) and disputed by Leaver et al. (2004). The majority of the mechanical drills were substitution drills that were conducted as whole class activities with the instructor presenting the model, then calling on an individual student to give the response, after which the instructor reinforced the answer by repeating the whole phrase. One activity on Day 1 and two activities on Day 2 were completed by the students in pairs.

The researchers created the PI materials according to the guidelines presented in Lee and VanPatten (2003) and Farley (2005). The activities in the PI treatment asked students to interpret the grammatical forms in the input and map those forms to destinational or locational meanings. The activities (see samples in Appendix E) included both aural and written input, referential and 
affective activities, and problem-solving tasks. None of the activities required learners to produce the new construction. Most of the activities were conducted as a whole class, with the instructor checking answers and surveying students' affective responses using show of hands and other techniques. The PI treatment materials included one metalinguistic task which made learners reflect on destinational forms found in the written input and sort them into groups by noun gender, so that they could observe the pattern of declensional endings and, it was hoped, link the accusative forms they encountered in destinational meanings to the correct declensional patterns.

\section{Place Vocabulary in the TI and PI Treatments}

The TI and PI treatments were balanced for place vocabulary items with 162 tokens (51 types in the PI treatment and 52 types in TI treatment). The complete list of vocabulary items, including their frequency in the treatment materials, is presented in Appendix C. Twenty-five of the tokens represent declension class 1; fourteen declensional class 4; seven represent declensional class 6; one represents declensional class 8 , one represents declensional class 10; two types were indeclinable nouns that look like declensional class 8; one type was a neuter plural noun (занятия - classes) that learners often misconstrue as a feminine singular noun because the ending - я can mark both feminine singular and neuter plural. Generic place nouns of neuter gender are underrepresented in both the TI and PI treatments because such place nouns are frequently of foreign origin, and thus are treated by Russian as indeclinable.

Procedures 
A week before the experiment, the researchers visited all sections to explain the general purpose of the study and to ask the students to sign consent forms. The study took place during two regular (50 minute) consecutive class sessions, and the two researchers conducted all treatment sessions at their respective institutions. At the first session participants completed a short background survey and the pre-test (approximately 10 minutes). Once the pre-test was collected, they received a treatment packet with materials for the two class days. The TI and PI treatment packets started by familiarizing students with vocabulary for places. Both TI and PI groups then received the same explicit information about the location/destination distinction and spent the remainder of day 1 working on destinational expressions. The treatment packets were collected at the end of day 1, and students had no homework assignment before the next class session. After a warmup on the second day, students completed activities contrasting locational and destinational phrases, and at 40 minutes into the class hour they were instructed to put away the treatment materials, whereupon they completed the post-test. Both the PI and TI treatments took approximately 75 minutes of regular class time over two consecutive days.

\section{Scoring}

The researchers scored the locational and destinational sentences in the pre- and post-tests, assigning 1 point for a correct answer, 0 for a missing or incorrect answer. In the production activities, if a student misspelled a word's stem (е.g., униберситет for университет [university], бассеине for бассейне [pool]), but got the ending correct, the answer was scored as correct. If a student misspelled the ending (e.g., -у in place of -ю or -й in place of -и), the answer was counted as wrong. Sentences containing distractors were not scored. 
In order to answer our third research question and explore how the two treatment types may have intereacted with student learning of the five different declensional classes of nouns, we calculated the Item Facility (hereafter IF) for each location-destination sentence used in the preand post-tests. IF is calculated by dividing the number of students answering the item correctly by the number of students in the group. IF ratings for test items range from .00 (very difficult) to 1.00 (very easy).

Results

The means and standard deviations for the pre-test and post-test interpretation and production tasks are listed in Table 3. Figure 1 presents a bar graph of the results of the interpretation tasks for both treatment groups, while Figure 2 presents the results of the production tasks. In Figure 3 the interpretation task results are broken down by location and destination sentences, while Figure 4 presents the production task results divided by location and destination sentences. Figures 5 and 6 present the results of the interpretation and production tasks divided by location and destinational sentences for the public university, while Figures 7 and 8 present the analogous results for the private university.

Pre-test

To verify that the groups were the same before starting the treatments, two ANOVAs were conducted on the pre-test scores, one using the interpretation task results as the dependent variable, and a second one with the production task results as the dependent variable. On the pre-test interpretation task, a main effect was found for treatment, $F(1,56)=4.376, \mathrm{p}=.041, \eta_{\mathrm{p}}{ }^{2}$ $=.072$, although no effect was found for institution, $\mathrm{F}(1,56)=1.960, \mathrm{p}=.167, \eta_{\mathrm{p}}{ }^{2}=.034$, nor was there an interaction between institution and treatment, $F(1,56)=1.045, \mathrm{p}=.311, \eta_{\mathrm{p}}{ }^{2}=.018$. On the 
pre-test production task no main effect was found for treatment, $F(1,56)=3.831, \mathrm{p}=.055, \eta_{\mathrm{p}}{ }^{2}$ $=.064$, nor for institution, $\mathrm{F}(1,56)=.025, \mathrm{p}=.874, \eta_{\mathrm{p}}{ }^{2}=.000$, nor was there an interaction between institution and treatment, $\mathrm{F}(1,56)=.506, \mathrm{p}=.480, \eta_{\mathrm{p}}{ }^{2}=.009$. We note, therefore, that the TI group had a significantly higher mean on the pre-test interpretation task than the PI group.

Interpretation Task

A repeated measures ANOVA using the overall interpretation task score as the dependent variable revealed a main effect for time, $F(1,56)=84.745, \mathrm{p}=.000, \eta_{\mathrm{p}}{ }^{2}=.602$ meaning that both treatment groups improved significantly from pre-test to post-test on the interpretation task. There was a significant interaction for time $x$ treatment, $F(1,56)=7.611, p=.008, \eta_{\mathrm{p}}{ }^{2}=.120$, with the PI treatment group improving significantly more from pre-test to post-test than the TI group (see Figure 1). There was a significant interaction for time $\mathrm{x}$ institution $(\mathrm{F}(1,56)=4.476, \mathrm{p}=.039$, $\left.\eta_{\mathrm{p}}{ }^{2}=.074\right)$ with the private university students improving significantly more than the public university students from pre-test to post-test in both treatment groups (see Figures 5 and 7). There was not a significant interaction for time $\mathrm{x}$ treatment $\mathrm{x}$ institution $(\mathrm{F}(1,56)=.491, \mathrm{p}=.487$, $\left.\eta_{\mathrm{p}}{ }^{2}=.009\right)$. When locational sentences were separated out from destinational sentences, there was no significant interaction for time $\mathrm{x}$ treatment for the interpretation of locational sentences $\left(\mathrm{F}(1,56)=1.331 \mathrm{p}=.253, \eta_{\mathrm{p}}^{2}=.023\right)$, although there was a significant interaction for time $\mathrm{x}$ treatment in the interpretation of destinational sentences $\left(F(1,56)=8.511, p=.005, \eta_{p}{ }^{2}=.132\right)$, with the PI group making significantly greater improvement from pre-test to post-test (see Figure 3).

Production Task 
A repeated measures ANOVA revealed a main effect for time $(F(1,56)=87.041, p=.000$, $\left.\eta_{\mathrm{p}}{ }^{2}=.609\right)$ meaning that both treatment groups improved significantly from pre-test to post-test on the production task. There was no significant interaction found for time $\mathrm{x}$ treatment $\left(\mathrm{F}(1,56)=.216, \mathrm{p}=.644, \eta_{\mathrm{p}}{ }^{2}=.004\right)$, which suggests that the PI groups performed just as well as the TI groups on producing locational and destinational forms, although the PI treatment did not require learners to produce a single form (see Figure 2). There was a significant interaction for time $\mathrm{x}$ institution $\left(\mathrm{F}(1,56)=5.857, \mathrm{p}=.019, \eta_{\mathrm{p}}{ }^{2}=.095\right)$, with students at the private university performing significantly better on producing destinational and locational phrases after both types of instruction (see Figures 6 and 8). There was no interaction for time $\mathrm{x}$ treatment $\mathrm{x}$ institution $\left(\mathrm{F}(1,56)=.630, \mathrm{p}=.431, \eta_{\mathrm{p}}{ }^{2}=.011\right)$.

When the production of locational sentences was separated out from destinational sentences, a main effect was observed for time $\left(F(1,56)=10.539, \mathrm{p}=.002, \eta_{\mathrm{p}}{ }^{2}=.158\right)$ and a significant interaction for time $x$ treatment $\left(F(1,56)=10.040, p=.002, \eta_{p}^{2}=.152\right)$, with students in the PI treatment making significant improvement from pre-test to post-test, while students in the TI group performed worse at making locational sentences on the post-test (see Figure 4). There was a significant interaction for time $\mathrm{x}$ institution $\left(\mathrm{F}(1,56)=5.214, \mathrm{p}=.026, \eta_{\mathrm{p}}{ }^{2}=.085\right)$, with the private university students making a very large gain in accuracy in producing locational sentences (see Figures 6 and 8). There was not a significant interaction for time $\mathrm{x}$ treatment $\mathrm{x}$ institution $\left(\mathrm{F}(1,56)=2.504, \mathrm{p}=.119, \eta_{\mathrm{p}}{ }^{2}=.043\right)$.

In the production of destinational sentences, a main effect was found for time $\left(\mathrm{F}(1,56)=91.106, \mathrm{p}=.000, \eta_{\mathrm{p}}^{2}=.619\right)$, and there is a significant interaction for time $\mathrm{x}$ treatment $\left(\mathrm{F}(1,56)=4.973, \mathrm{p}=.030, \eta_{\mathrm{p}}{ }^{2}=.082\right)$ with the TI groups producing significantly more accurate destinational sentences (see Figure 4). There was not a significant interaction for time $\mathrm{x}$ 
institution $\left(\mathrm{F}(1,56)=1.390, \mathrm{p}=.243, \eta_{\mathrm{p}}{ }^{2}=.024\right)$ nor time $\mathrm{x}$ treatment $\mathrm{x}$ institution $(\mathrm{F}(1,56)=.132$, $\left.\mathrm{p}=.718, \eta_{\mathrm{p}}^{2}=.002\right)$

Learner Accuracy and Noun Declensional Classes

Table 4 presents the Item Facilty averages and standard deviations broken down by noun classes and treatment groups for the interpretation task. The interpretation task did not include any neuter nouns with a hard ending, so that category has not been included in the summary table. Table 5 presents the IF averages and standard deviations from the production activity when grouped by noun classes.

\section{Discussion \\ Research Question 1}

There was significant improvement on both interpretation and production tasks from pretest to post-test for both treatment groups; however, there were significant interactions found for treatment type, and so the answer to our first research question is positive. Even for a language like Russian and a processing problem that involves complex morphology, PI is more effective than TI (operationalized as mechanical drills), since the PI students improved more than the TI students on the interpretation task, and performed statistically as well as the TI group on the production tasks. The results of the current study are similar to those reported in the original VanPatten and Cadierno (1993) article and in subsequent PI research. Thus an instructional focus on learning to recognize the distinction between locational and destinational phrases in the language input translates into student gain in producing these forms, even though students were not required to produce a single form during the 75 -minute treatment. The improvement of the 
PI groups on the sentence interpretation task in this study is of special interest, since on the pretest the TI groups scored significantly better on this measure. Thus the larger improvement in the PI groups in the post-test suggests that PI is very effective at increasing students' abilities to map forms to meaning in oral input, and the PI treatment was most helpful in improving learners' abilities to map the accusative case forms to their destinational meaning.

Furthermore, when we examined student performance on the production task by sentence type, it became clear that TI helped students make statistically significant progress only in producing destinational sentences. The TI groups seemingly overgeneralized the grammar for expressing destination, since their performance in producing locational phrases deteriorated slightly from pre-test to post-test. This is surprising, since the treatment materials included two exercises requiring students to produce locational phrases in contrast to destinational forms. The PI group, in contrast, improved at producing destinational phrases and was statistically superior to the TI group in making locational sentences. We conclude that the PI treatment actually taught learners to recognize the distinction between the destinational and locational sentences, and therefore primed them to be better at production of both forms.

\section{Research Question 2}

The answer to our second research question is negative; in none of the statistical tests did we find an interaction for time $\mathrm{x}$ treatment $\mathrm{x}$ institution. Thus we cannot conclude that one type of instruction is better for learners at one kind of institution than at another. In fact, given the significant interaction between time $\mathrm{x}$ institution for both the interpretation and production tasks, it is clear that students at the selective private university benefited from instruction (of either type) more than students at the public university. Nevertheless, in light of the conclusion to 
research question 1 of this study, we argue that PI can be a very effective tool for students at both highly selective elite institutions and for public institutions.

\section{Research Question 3}

We take an exploratory, qualitative approach to examining the IF data for patterns. When we look at the IF for noun types in the interpretation task, we note that for both treatment groups test items containing feminine nouns became easier from pre-test to post-test. It is likely that students had an easier time with feminine nouns, since the feminine endings are distinct for nominative, accusative, and prepositional (i.e., there is a one-to-one relationship between form and case), and also since acoustically the feminine accusative ending (-y for declension class 4 and -ю for declension class 6) is quite prominent, as the vowel sound $/ \mathrm{u} /$ does not undergo reduction in spoken Russian. For masculine and neuter nouns in declensional classes 1 and 10, the mapping of surface forms to meaning is complex, and students in the PI treatment groups had an easier time mapping those endings to their meanings than the TI treatment groups, for whom these items remained almost as difficult on the post-test as they were on the pre-test.

When we examine the results of the production task, we note that for both the PI and TI groups nouns in all declensional classes got easier, although neuter nouns remain almost as difficult for the TI group on the post-test as on the pre-test. It is hard to speculate about what the TI groups found difficult about this noun class, although declinable neuter place nouns are less common in the language than other declensional classes, and they were not as frequent in the PI and TI treatment materials as nouns from other classes.

For the PI groups it is the set of feminine and neuter nouns with -ий stems that remain relatively difficult. This is perhaps not surprising, since both types of nouns require surface 
forms that deviate from general patterns: in the prepositional case, both end in $-\mathrm{U}$, when the other three noun types end in -e. In the accusative case, feminine nouns with -ий stems require the /u/ ending to be spelled with the letter ю rather than the letter y typical of feminine hard stem nouns. It is possible that the PI tasks alone do not push students sufficiently to notice those details that are important for accuracy in the written language. This suggests that PI tasks, while effective in teaching the meaning of a grammatical feature, should be followed up with opportunities for students to engage in meaning-based production activities in speaking and writing that target less salient features that are important in formal accuracy.

The greater change in IF values from pre-test to post-test on the production tasks may also have to do with the greater comfort level that students often have with written input over aural input. While there was an overall time limit on the production task, learners could read, reread, and compare sentences in the task, since all 15 prompts were available to them at one time. In answering items on the interpretation task, students heard the item only once and had no more than 5 seconds to check their answer before hearing the next item.

Conclusions

The present study's results have implications both for the PI research agenda, pedagogical practice and materials development. This is the first PI study to look at a processing problem that is encoded in a wide range of morphemes. Most PI studies targeting the Lexical Preference Principle narrow their treatment to a single grammatical form. This study, for which students needed to map five surface morphological forms to two complementary meanings, still showed PI to be more effective than TI for interpreting those forms, and statistically as effective as TI for 
producing them; it does not seem to have overstrained the PI dictum of «present one thing at a time» (Lee and VanPatten, 2003, p. 154).

We note a limitation to the data presented here. The Effect size as calculated by Partial eta squared for the variable time is quite large (.602 and .609 for the interpretation and production tasks, respectively). Hence time spent on instruction in general, whether in PI or TI, accounts for the largest part of the variance between pre- and post-test scores. For logistical reasons the study could not include a control group, but had one been included, it is possible that the Effect size for the variable time would be smaller, and more of the variance might be explained by treatment type and other factors.

More important than the mere fact of both groups' improvement, and significant especially for Russian language pedagogy, is the nature of each group's progress. The PI group had superior performance on the interpretation task and improved at producing both destinational and locational phrases; the TI group's improvement in production extended only to destinational expressions. Our finding that the TI group overgeneralized one construction is another piece of evidence for what VanPatten and Wong termed the "unnoticed negative effect of traditional grammar instructional formats" (VanPatten \& Wong, 2003, 112).

Based on our results we agree with the conclusion reached by Wong and VanPatten (2003) that mechanical drills are not necessary for language acquisition, even when targeting a complex form-meaning mapping in Russian. Nevertheless, we note that in our research students did learn something of the targeted forms from TI. Because TI can produce a certain kind of result, and because a classroom with production-focused TI activities appears to engage students because they are 'always talking' (i.e., producing morphologically accurate surface structures), it may seem to some teachers that TI 'works'. As the study results suggest, however, TI may 
'work', but only in a very limited way, and it can be replaced by PI and other kinds of focus-onform instruction. ${ }^{3}$

The challenge remains to take the results of this study and develop and disseminate a range of model PI and SI treatments for common grammar topics that can replace the mechanical exercises that still account for the bulk of grammar practice in current Russian textbooks at the elementary level (Comer, forthcoming). We started that work in our earlier study (Comer \& deBenedette, 2010), but more remains to be done. In addition to rethinking Russian grammar instruction within a PI/SI framework, the field will need to work on teacher training so that materials are implemented in a way that never separates instruction in language form from attention to meaning and communication.

PI offers the possibility of adjusting even the most basic instruction in Russian morphology and syntax to include (rather than ignore) a focus on meaning, and to push learners to interpret as well as produce forms accurately. Some of the most challenging features of Russian grammar are precisely ones where subtle differences in morphology and syntax result in large changes in meaning, changes that language learners are likely to miss entirely or seriously misinterpret (e.g., с вас / с вами [from you / with you]; Мы знаем Пушкина/Пушкину [We know Pushkin \{male\}/Pushkin \{female\}]; он купил билет в Москве / он купил билет в Москву [he bought a ticket in Moscow / he bought a ticket to Moscow]). In the case of the куда [where to - destination] vs. где [where at - location] distinction presented in this study, initial presentation of the distinction (along with much of the output-focused practice in textbooks) occurs alongside work on verbs of motion. The lexical and collocational reach of the distinction, however, stretches beyond that initially encountered contrast between «motion verbs» and verbs like «to live» and «to work». Learners must eventually be able to associate directionality with 
both verbs and nouns that do not obviously appear to encode physical motion (e.g., билет на концерт [a ticket to the concert]; записываться на курс [to sign up for a course]; звонить в кинотеатр [to phone the movie theater]). When more advanced learners encounter verbs of position and positioning («the book stood on the shelf» vs. «he stood-put the book on[to] the shelf»; «the coat hung on the hook» vs. she hung-put the coat on(to) the hook»), they must not only learn multiple verbs where English may have only one («to hang»), they must also apply the куда / где [where to - destination / where at - location] distinction in a new lexical environment. Because PI's structured input activities help learners link forms with meaning and focus on accurate interpretation of forms, they are a highly appropriate pedagogical tool for tackling these issues. Creating such activities requires instructors and materials designers to think differently about how form and meaning interact, and it requires instructors to think about ways to manipulate language input that force learners to attend to the meaning(s) inherent in grammatical forms. As challenging as it may be to create such new materials in languages where they have as yet been little used, the evidence from PI research shows the benefits of this approach to input in instruction. 


\section{Acknowledgments}

We would like to thank Mr. Mickey Waxman for his assistance with the statistical analyses presented in this study. The Center for Russian, East European and Eurasian Studies at the University of Kansas provided assistance with photocopying the classroom materials. We would like to thank Nina Vyatkina, Amy Rossomondo and Marc Greenberg for their helpful suggestions on earlier drafts of this manuscript, and Katie Kahle for assistance conducting the study. We are responsible for any inaccuracies. 


\title{
Notes
}

\author{
${ }^{1}$ The breakdown and numbering of declensional classes in this article departs from the \\ traditional presentation of Russian declension patterns in the standard academic grammars \\ (Cubberley, 2002) in an attempt to make the researchers' grammatical choices and focus clearer \\ to an audience of non-Russian specialists.
}
${ }^{2}$ Although библиотек [library] is not the dictionary form of this lexical item, the form (the genitive plural of the word библиотека) does exist, and learners can easily encounter it in language input. Thus, it is critical for learners to identify both a word's usage and its dictionary form when comprehending a sentence.
${ }^{3}$ A limitation of our study is that we operationalized TI as mechanical drills alone (rather than using a mix of mechanical, meaningful and communicative drills), and, as one reviewer pointed out, classroom practice is usually not so limited. We agree that classroom work on grammar may feature a wider range of output-based grammar activities than the ones used in the TI part of this research study. We question, however, the extent to which existing grammar materials for Russian make learners work on comprehending (rather than producing) forms, and check learners' processing of input before production begins. Furthermore, given that mechanical drills are not necessary for acquisition to occur, there would seem to be no reason to have the gamut of practice activities on any given topic start with mechanical drills as a "first step" in learning grammar forms.


References

Benati, A. G. (2001). A comparative study of the effects of processing instruction and outputbased instruction on the acquisition of the Italian future tense. Language Teaching Research, 5, 95-127.

Benati, A. G. (2004). The effects of structured input and explicit information on the acquisition of Italian future tense. In B. VanPatten (Ed.), Processing instruction: Theory, research, and commentary (pp. 207-255). Mahwah, NJ: Erlbaum.

Benati, A. G. (2005). The effects of PI, TI, and MOI in the acquisition of the English simple past tense. Language Teaching Research, 9, 67-113.

Benati, A. G. \& Lee, J. F. (2008). Grammar acquisition and processing instruction: Secondary and cumulative effects. Bristol: Multilingual Matters.

Benati, A. G. \& Lee, J. F. (2010). Processing instruction and discourse. New York: Continuum. Benati, A. G. \& Lee, J. F. with McNulty, E. M. (2010). Exploring the effects of processing instruction on a discourse-level guided composition with the Spanish subjunctive after the adverb cuando. In Benati, A. G. \& Lee, J. F., Processing instruction and discourse (pp. 97-147). New York: Continuum.

Cadierno, T. (1995). Formal instruction from a processing perspective: an investigation into the Spanish past tense. The Modern Language Journal, 79, 179-193.

Comer, W. J. (forthcoming). Communicative Language Teaching and Russian: The Current State of the Field. In Makarova, V. (Ed.), Russian language studies in Canada and the USA: The new focus. London: Anthem Press.

Comer, W. J. \& deBenedette, L. (2010). Processing Instruction and Russian: Issues, Materials, and Preliminary Experimental Results. Slavic and East European Journal, 54(1), 118-46. 
Cubberley, P. (2002). Russian: A linguistic introduction. Cambridge UK: Cambridge UP. Culman, H., Henry, N. \& VanPatten, B. (2009). The role of explicit information in instructed SLA: An on-line study with processing instruction and German accusative case inflections. Unterrichtspraxis, 42(1), 19-31.

Farley, A. (2005). Structured input: Grammar instruction for the acquisition-oriented classroom. New York, McGraw-Hill.

Leaver, B. L., Rifkin, B., \& Shekhtman, B. (2004). Apples and oranges are both fruit, but they don't taste the same: A response to Wynne Wong and Bill VanPatten. Foreign Language Annals, $37(1), 125-132$.

Lee, J. F. \& Benati, A. G. (2007a). Delivering processing instruction in classrooms and in virtual contexts: Research and practice. London: Equinox.

Lee, J. F. \& Benati, A. G. (2007b). Second language processing: An analysis of theory, problems, and possible solutions. London: Continuum.

Lee, J. F. \& Benati, A. G. (2009). Research and perspectives on processing instruction. New York: Mouton de Gruyter.

Lee, J. F. \& Benati, A. G. with Aguilar-Sánchez, J. and McNulty, E. M. (2007). Comparing three modes of delivering processing instruction on preterite/imperfect distinction and negative informal commands in Spanish. In Lee, J. F. \& Benati, A. G. Delivering processing instruction in classrooms and in virtual contexts: Research and practice (pp. 73-98). London: Equinox. Lee, J. F. \& VanPatten, B. (2003). Making communicative language teaching happen. 2nd ed. New York: McGraw-Hill.

Lubensky, S., Ervin, G., McLellan, L., \& Jarvis, D. (2001). Nachalo. Book 1. 2nd ed. Boston, MA: McGraw-Hill. 
Morton, A., Yakimova, L., \& VanPatten, B. (2011, January). The role of explicit information in the processing of non-canonical sentences in Russian L2. Paper presented at the Annual Meeting of the American Association of Teachers of Slavic and East European Languages, Pasadena, CA. VanPatten, B., ed. (2004). Processing instruction: Theory, research, and commentary. Mahwah, NJ: Lawrence Erlbaum Associates.

VanPatten, B. \& Cadierno, T. (1993). Input processing and second language acquisition: A role for instruction. The Modern Language Journal, 77, 45-57.

VanPatten, B. \& Wong, W. (2004). Processing instruction and the French causative: Another replication. In VanPatten, B., Processing instruction: Theory, research, and commentary (pp. 97118). Mahwah, NJ: Lawrence Erlbaum Associates.

Wong, W. (2010). Exploring the effects of discourse-level structured input activities with French causative. In Benati, A. G. \& Lee, J. F. Processing instruction and discourse (pp. 198-216). New York: Continuum.

Wong, W. \& VanPatten, B. (2003). The Evidence is IN: Drills are OUT. Foreign Language Annals, 36(3), 403-423.

Wong, W. \& VanPatten, B. (2004). Beyond experience and belief (or waiting for the evidence): A reply to Leaver, et al.'s 'Apples and oranges.' Foreign Language Annals, 37(1), 133-142. 
Processing Instruction and Russian: Further

Table 1: Place nouns according to gender and declensional classes

\begin{tabular}{|l|l|l|}
\hline Russian Word & Gender & Declensional Class \\
\hline университет [university] & Masc. & 1. hard consonant \\
\hline корабль [ship] & Masc. & 2. soft consonant \\
\hline кафетерий [cafeteria] & Masc. & 3. stem ending in -ий- \\
\hline школа [school] & Fem. & 4. hard stem \\
\hline спальня [bedroom] & Fem. & 5. soft stem \\
\hline Россия [Russia] & Fem. & 6. stem ending in -ий- \\
\hline церковь [church] & Fem. & 7. stem in soft sign \\
\hline озеро [lake] & Neut. & 8. hard stem \\
\hline море [sea] & Neut. & 9. soft stem \\
\hline общежитие [dormitory] & Neut. & 10. stem ending in -ий- \\
\hline
\end{tabular}


Processing Instruction and Russian: Further

Table 2: Case endings by gender and declensional class

\begin{tabular}{|l|l|l|l|}
\hline Gender \& & Nominative & Accusative & Prepositional \\
(with в/на conveys & (with в/на conveys \\
direction) & location)
\end{tabular}


Processing Instruction and Russian: Further

Table 3: Pre-test and Post-test scores by treatment type, task type, and institution

\begin{tabular}{|c|c|c|c|c|c|c|}
\hline \multicolumn{2}{|l|}{ Variables } & & \multicolumn{2}{|c|}{ Pre-test } & \multicolumn{2}{|c|}{ Post-test } \\
\hline & Institution & $\mathrm{N}$ & Mean & $\begin{array}{c}\text { Std. } \\
\text { Deviation }\end{array}$ & Mean & $\begin{array}{c}\text { Std. } \\
\text { Deviation }\end{array}$ \\
\hline \multicolumn{7}{|c|}{$\begin{array}{l}\text { Interpretation } \\
(\max .10)\end{array}$} \\
\hline Processing & U1 & 22 & 3.36 & 1.53 & 6.27 & 2.29 \\
\hline \multirow[t]{2}{*}{ Instruction } & U2 & 10 & 3.50 & 1.18 & 8.20 & 1.55 \\
\hline & Total & 32 & 3.41 & 1.41 & 6.88 & 2.25 \\
\hline Traditional & U1 & 20 & 3.75 & 1.12 & 5.35 & 2.46 \\
\hline \multirow[t]{2}{*}{ Instruction } & U2 & 8 & 4.63 & .92 & 7.13 & 1.96 \\
\hline & Total & 28 & 4.00 & 1.12 & 5.86 & 2.43 \\
\hline \multirow[t]{3}{*}{ Total } & U1 & 42 & 3.55 & 1.35 & 5.83 & 2.39 \\
\hline & U2 & 18 & 4.00 & 1.19 & 7.72 & 1.78 \\
\hline & Total & 60 & 3.68 & 1.31 & 6.40 & 2.37 \\
\hline \multicolumn{7}{|l|}{$\begin{array}{l}\text { Production } \\
(\max .12)\end{array}$} \\
\hline Processing & U1 & 22 & 3.77 & 1.85 & 6.91 & 4.34 \\
\hline \multirow[t]{2}{*}{ Instruction } & U2 & 10 & 3.30 & 2.00 & 9.50 & 2.88 \\
\hline & Total & 32 & 3.63 & 1.88 & 7.72 & 4.08 \\
\hline Traditional & U1 & 20 & 4.45 & 2.16 & 7.90 & 2.36 \\
\hline Instruction & U2 & 8 & 4.75 & 1.16 & 9.75 & 1.67 \\
\hline
\end{tabular}


Processing Instruction and Russian: Further

\begin{tabular}{|l|l|r|r|r|r|r|}
\hline & Total & 28 & 4.54 & 1.91 & 8.43 & 2.32 \\
\hline Total & U1 & 42 & 4.10 & 2.01 & 7.38 & 3.53 \\
\cline { 2 - 7 } & U2 & 18 & 3.94 & 1.80 & 9.61 & 2.35 \\
\cline { 2 - 7 } & Total & 60 & 4.05 & 1.93 & 8.05 & 3.37 \\
\hline
\end{tabular}


Processing Instruction and Russian: Further

Table 4: Item Facility Averages (Standard Deviations) for interpretation task by treatment types and noun declension classes

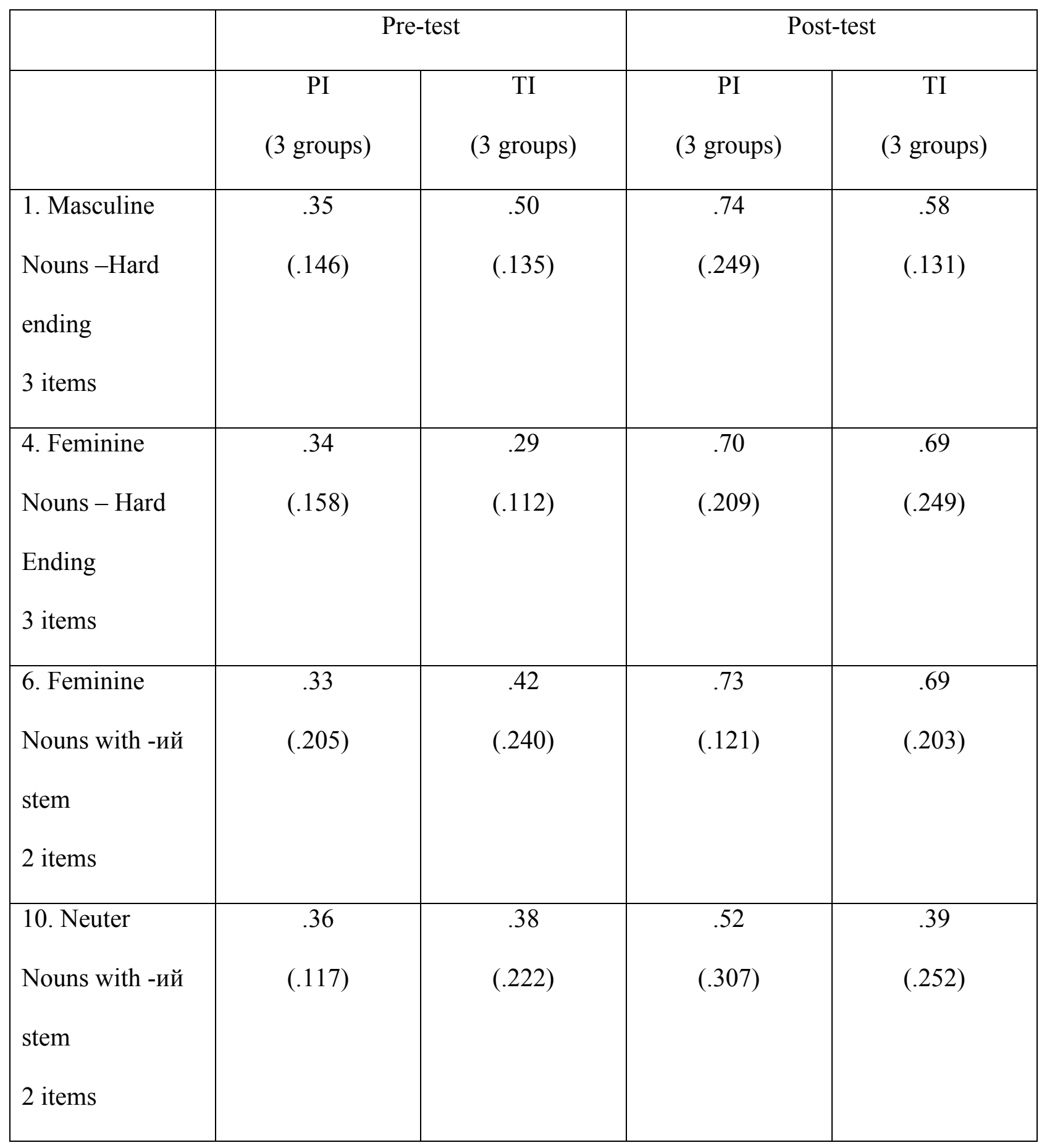


Processing Instruction and Russian: Further

Table 5: Item Facility Averages (Standard Deviations) for production task by treatment types and noun declension classes

\begin{tabular}{|c|c|c|c|c|}
\hline & \multicolumn{2}{|c|}{ Pre-test } & \multicolumn{2}{|c|}{ Post-test } \\
\hline & $\begin{array}{c}\text { PI } \\
\text { (3 groups) }\end{array}$ & $\begin{array}{c}\text { TI } \\
\text { (3 groups) }\end{array}$ & $\begin{array}{c}\text { PI } \\
\text { (3 groups) }\end{array}$ & $\begin{array}{c}\text { TI } \\
\text { (3 groups) }\end{array}$ \\
\hline $\begin{array}{l}\text { 1. Masculine } \\
\text { Nouns -Hard } \\
\text { ending } \\
4 \text { items }\end{array}$ & $\begin{array}{c}.36 \\
(.283)\end{array}$ & $\begin{array}{c}.42 \\
(.302)\end{array}$ & $\begin{array}{c}.67 \\
(.187)\end{array}$ & $\begin{array}{c}.80 \\
(.238)\end{array}$ \\
\hline $\begin{array}{l}\text { 4. Feminine } \\
\text { Nouns - Hard } \\
\text { Ending } \\
4 \text { items }\end{array}$ & $\begin{array}{c}.28 \\
(.191)\end{array}$ & $\begin{array}{c}.34 \\
(.256)\end{array}$ & $\begin{array}{c}.66 \\
(.190)\end{array}$ & $\begin{array}{c}.74 \\
(.311)\end{array}$ \\
\hline $\begin{array}{l}\text { 6. Feminine } \\
\text { Nouns with -ий } \\
\text { stem } \\
1 \text { item }\end{array}$ & $\begin{array}{c}.34 \\
(.091)\end{array}$ & $\begin{array}{c}.44 \\
(.063)\end{array}$ & $\begin{array}{c}.47 \\
(.120)\end{array}$ & $\begin{array}{c}.90 \\
(.093)\end{array}$ \\
\hline $\begin{array}{l}\text { 8. Neuter Nouns } \\
\text {-Hard ending } \\
2 \text { items }\end{array}$ & $\begin{array}{c}.27 \\
(.098)\end{array}$ & $\begin{array}{c}.40 \\
(.231)\end{array}$ & $\begin{array}{c}.66 \\
(.191)\end{array}$ & $\begin{array}{c}.41 \\
(.183)\end{array}$ \\
\hline $\begin{array}{l}\text { 10. Neuter } \\
\text { Nouns with -ий } \\
\text { stem }\end{array}$ & $\begin{array}{c}.30 \\
(.224)\end{array}$ & $\begin{array}{c}.27 \\
(.098)\end{array}$ & $\begin{array}{c}.46 \\
(.081)\end{array}$ & $\begin{array}{c}.80 \\
(.155)\end{array}$ \\
\hline
\end{tabular}


Processing Instruction and Russian: Further

\begin{tabular}{|l|l|l|l|l|}
\hline 1 item & & & & \\
\hline
\end{tabular}


Click here to download high resolution image

\section{Interpretation Task: Pre- \& Post-test Scores by Treatment}

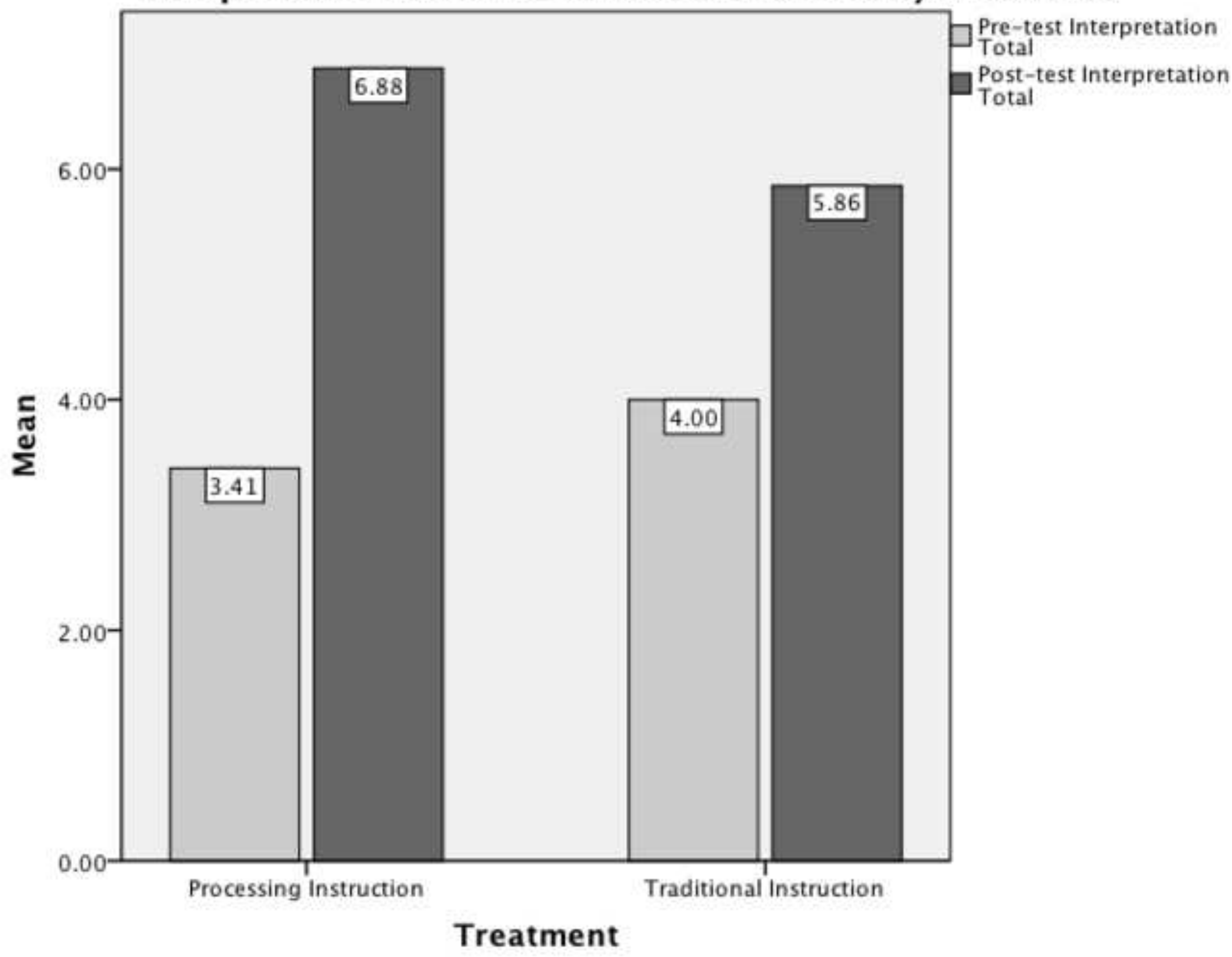


Click here to download high resolution image

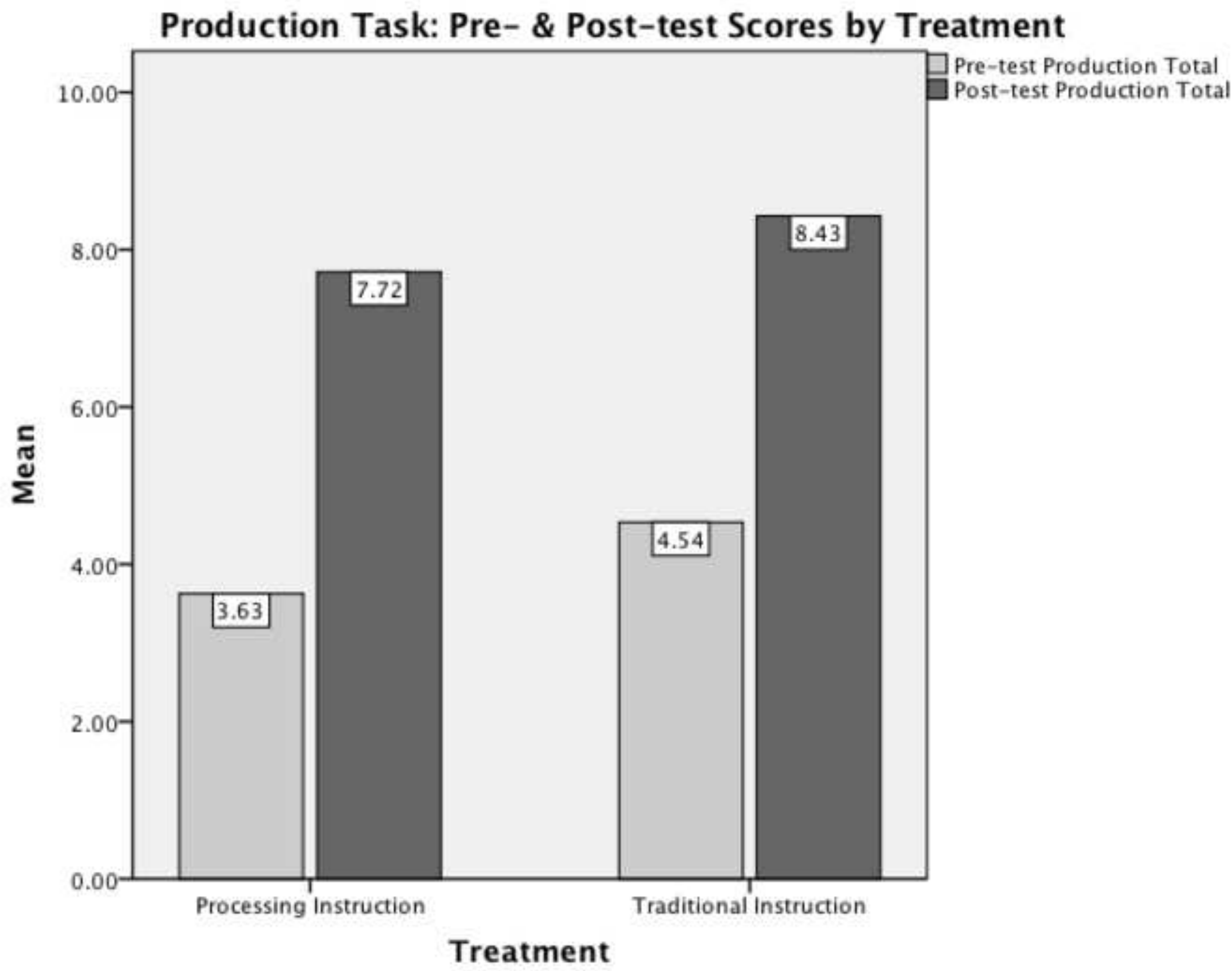




\section{Interpretation Results by Location and Destination}

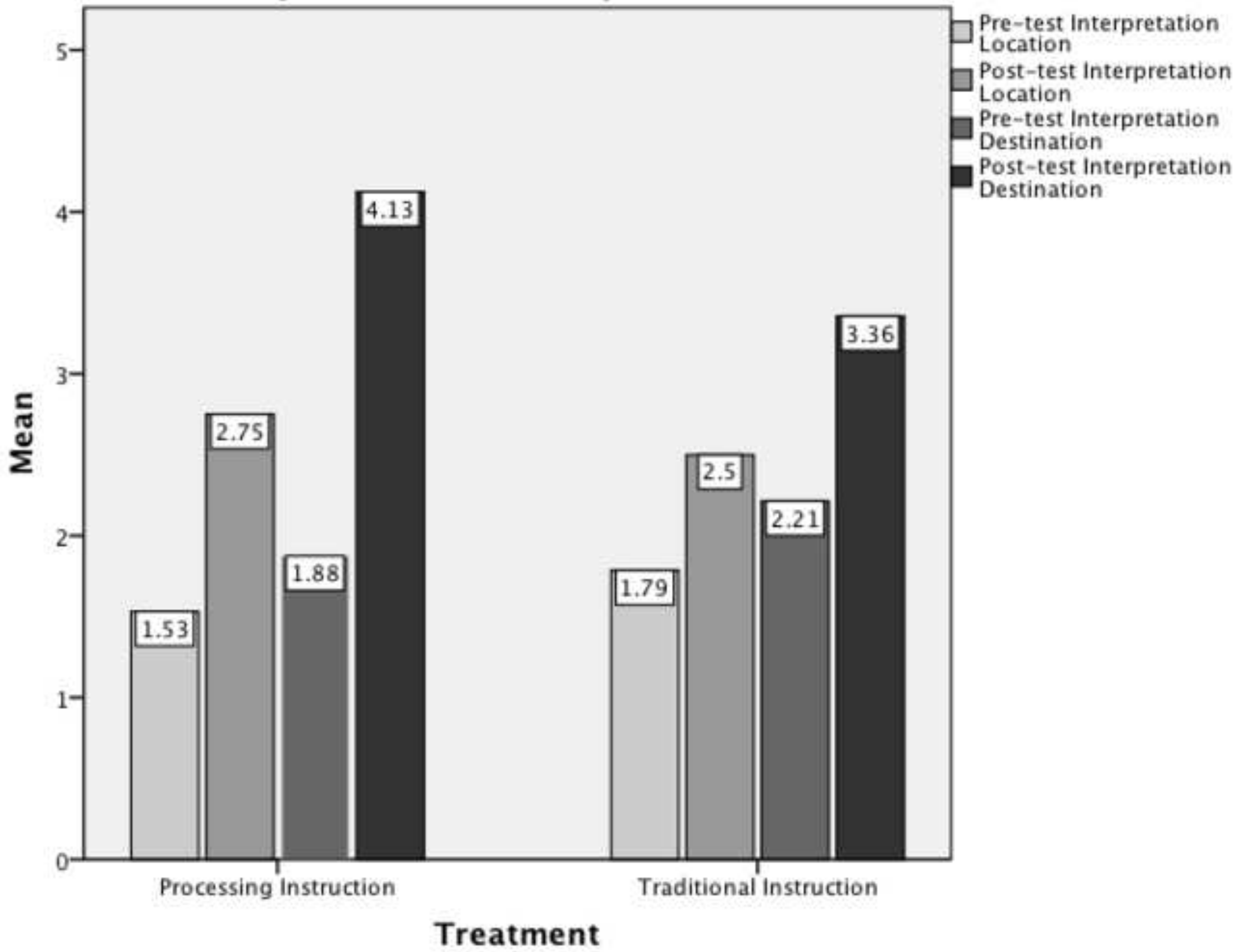




\section{Production Results by Location and Destination}

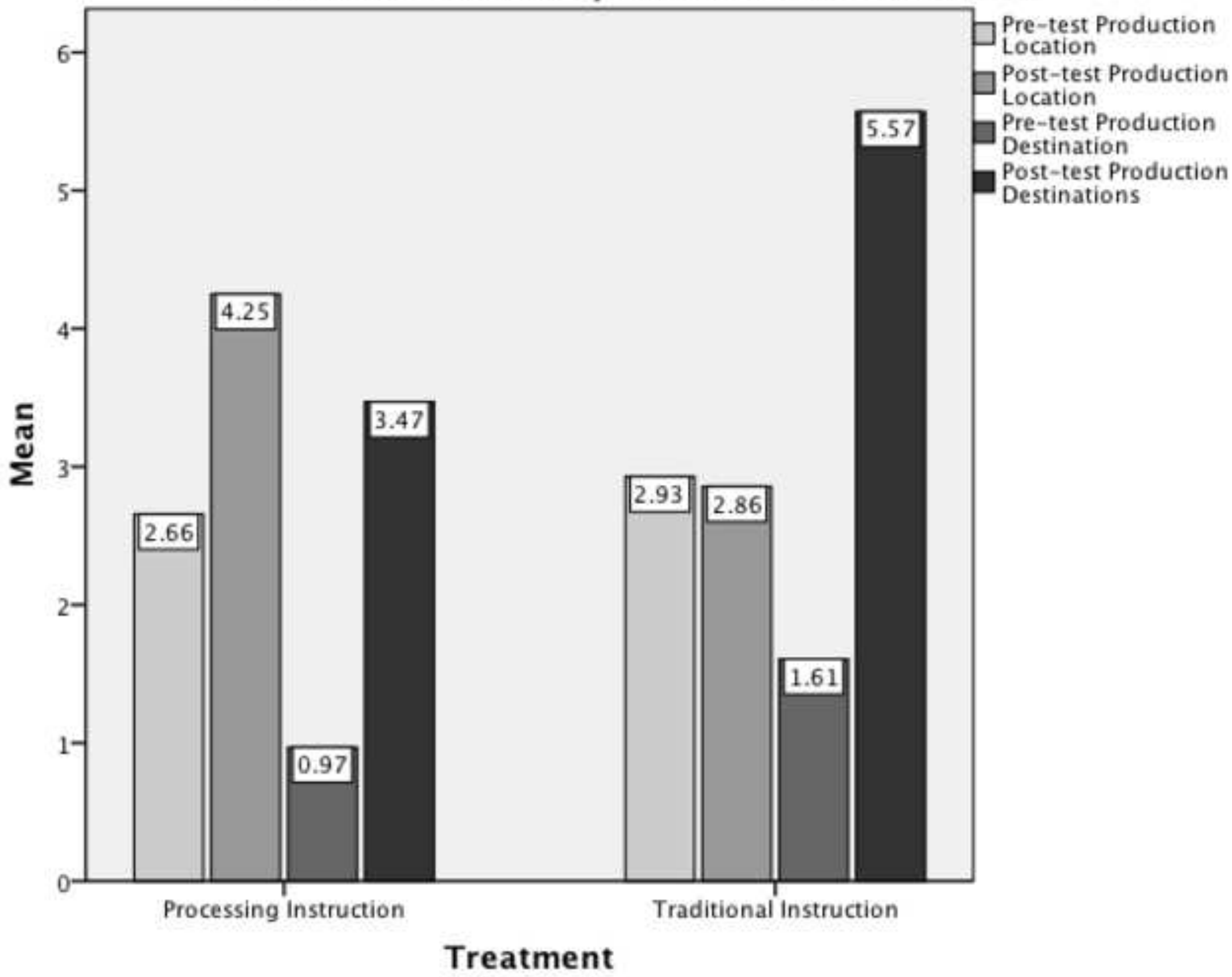


Click here to download high resolution image

\section{Interpretation Results by Location and Destination by Institution Type}

Institution: Public University

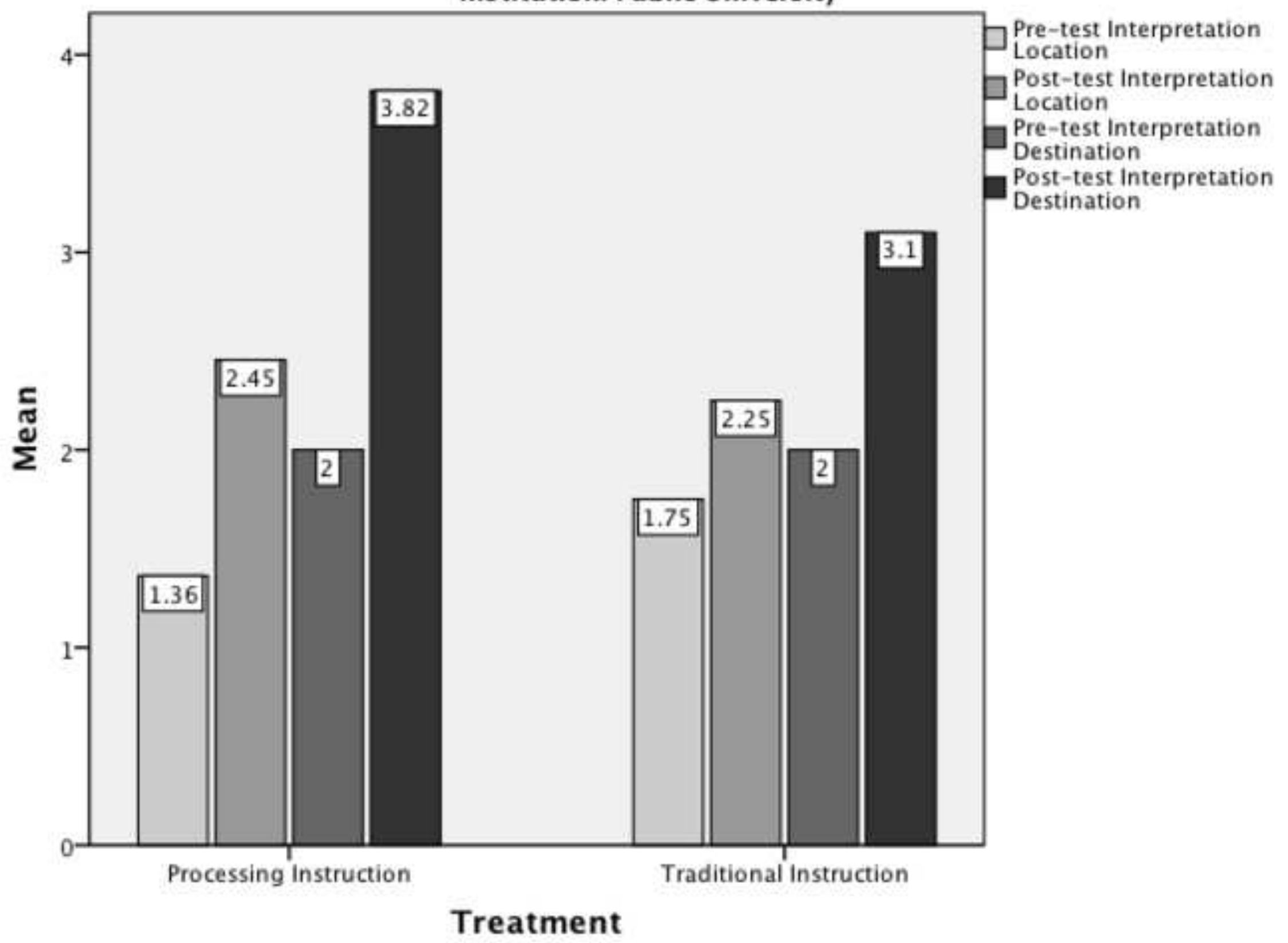


Production Results by Location and Destination by Institution Type Institution: Public University

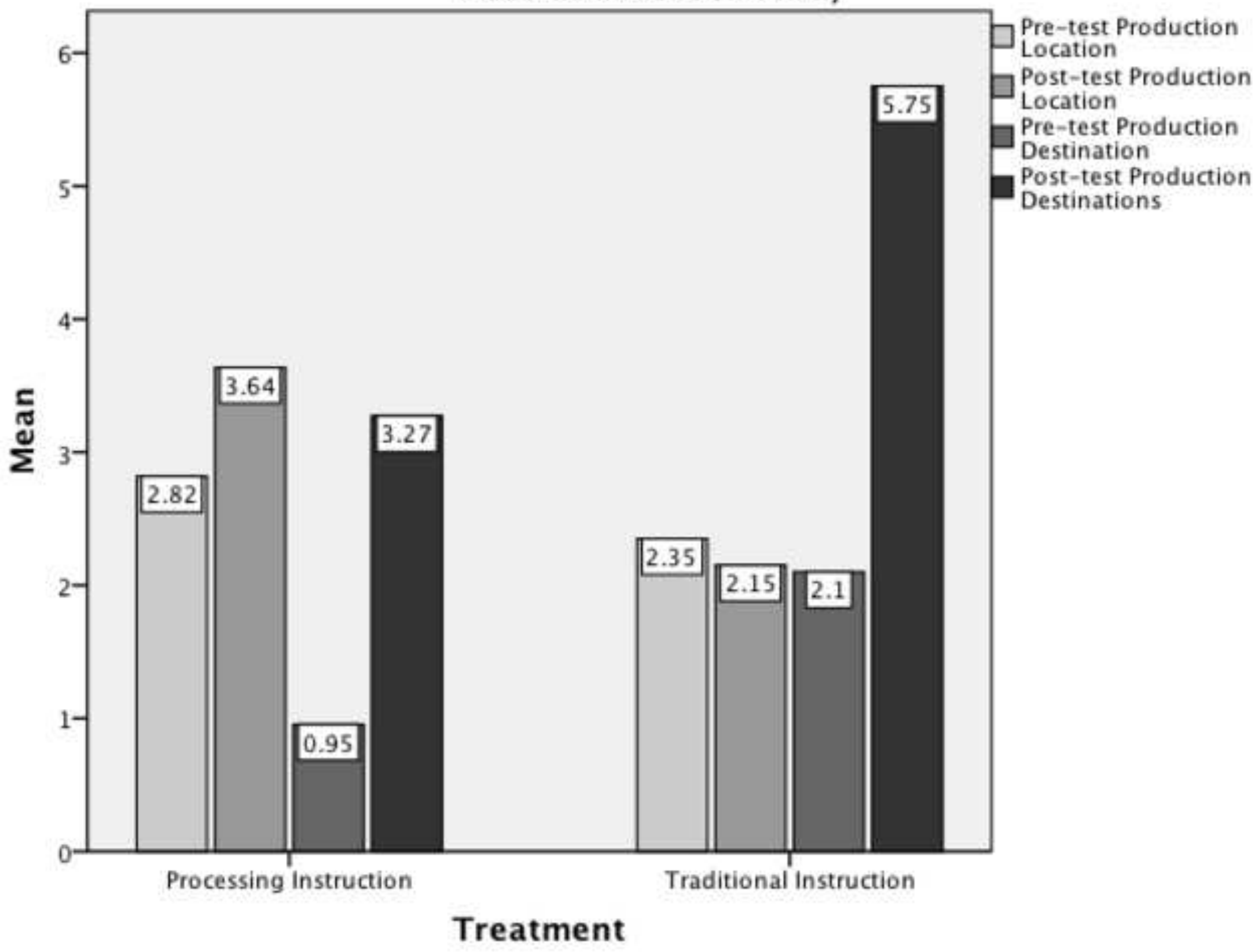




\section{Interpretation Results by Location and Destination by Institution Type}

Institution: Private

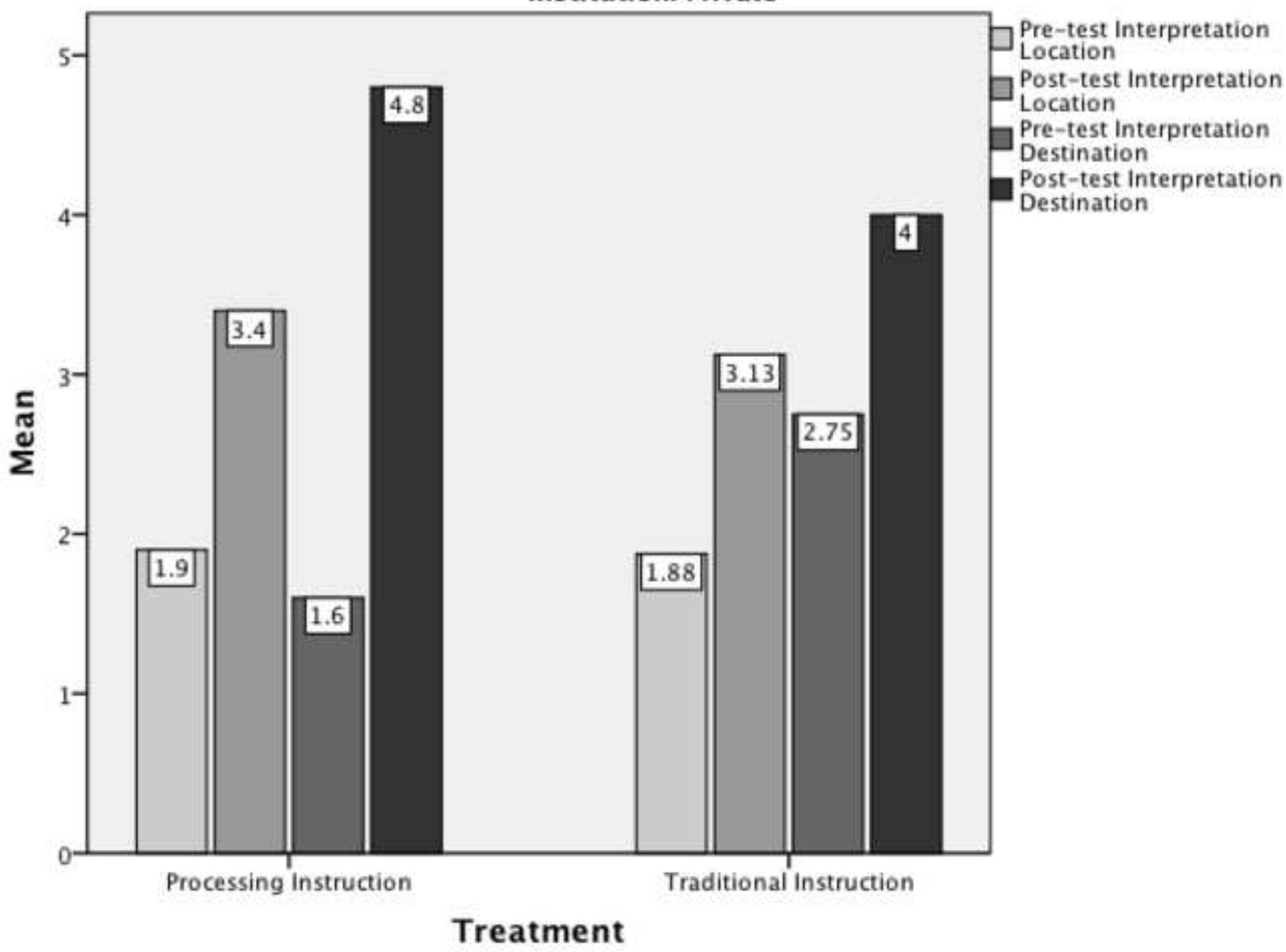




\section{Production Results by Location and Destination by Institution Type} Institution: Private

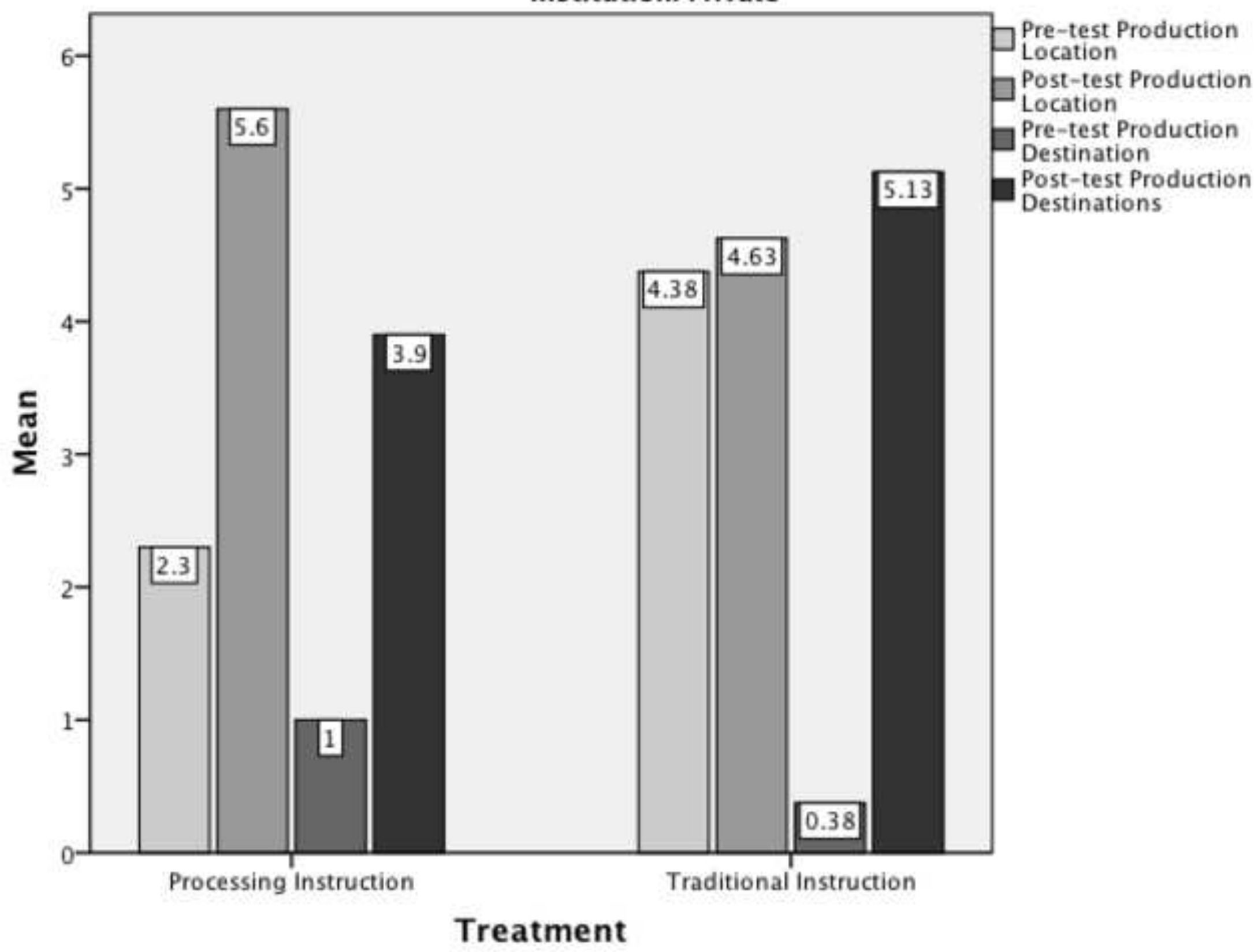




\section{Appendix A: Interpretation Task directions and sentences}

Processing Instruction and Russian: Further

Appendix A. Interpretation task from pre- and post-tests

Directions: You will hear 12 sentences; check the column that best reflects the meaning of the sentence. If the subject of the sentence refers to being in a place or at a place, then put a check mark in the "in a location" box. If the subject is headed to a destination or is going to a place, then check the "Headed to a destination." Some sentences will not contain either a location or destination; check the "neither" box. You will hear the sentences only once.

\begin{tabular}{|r|c|c|c|}
\hline & In a location & Headed to a destination & Neither \\
\hline 1. & & & \\
\hline 2. & & & \\
\hline
\end{tabular}

Sentences read to the students in Version A

1. Лена сейчас в библиотеке. [Lena is now at the library.]

2. Маша и Дима сегодня в Москву. [Masha and Dima are off to Moscow today.]

3. Профессор Петровский сейчас на лекции. [Professor Petrovskii is now at a lecture.]

4. Мы сейчас знаем Саратов. [We now know Saratov.]

5. Студенты сейчас на стадион. [The students are now off to the stadium.]

6. Таня сегодня в общежитии. [Tanya is now at the dormitory.]

7. Миша сегодня в Англию. [Misha is heading to England today.]

8. Вот сегодня Кострома. [That is Kostroma today.]

9. Света сейчас на дискотеку. [Sveta is now headed to the disco.]

10. Джим сегодня в спортзал. [Jim is headed to the gym today.]

11. Мы сейчас в общежитие. [We are now off to the dormitory.] 
Processing Instruction and Russian: Further

12. Наталья Ивановна сегодня в музеe. [Natalya Ivanovna is at the museum today.]

Sentences read to the students in version B

1. Вова сейчас в парк. [Vova is now off to the park.]

2. Джим сегодня в Калифорнии. [Jim is in California today.]

3. Сергей Петрович сегодня в банке. [Sergei Petrovich is now at the bank.]

4. Соседи сегодня на концерт. [Sasha is off to a concert today.]

5. Мы сейчас в общежитие. [We are now off to the dormitory.]

6. Галя сегодня в библиотеку. [Galya is off to the library today.]

7. Саша сейчас на дискотеке. [Sasha is now at the disco.]

8. Мы сейчас знаем Тулу. [We now know Tula.]

9. Джейн сейчас в Россию. [Jane is now headed to Russia.]

10. Таня сейчас в общежитии. [Tanya is now at the dormitory.]

11. Вот сегодня Курск. [That's Kursk today.]

12. Анна Антоновна сегодня в Америку. [Anna Antonovna is headed to America today.] 


\section{Appendix B: Production Task directions and sentences}

1 Processing Instruction and Russian: Further

Appendix B. Production task from the Pre- and Post-tests

Directions: Complete the sentence with a word cued in the picture. You will write the word in

Russian in the correct form. Pay attention to the meaning of the sentence to determine whether it expresses destination, location or another meaning.

\begin{tabular}{|l|c|}
\hline Example: & $\{$ clip art image of a library $\}$ \\
We study at & library \\
\hline
\end{tabular}

You will write: We study at the library. Your answer will be in Russian.

Vocabulary Reminder:

\begin{tabular}{|l|l|}
\hline Мы были $=$ & we were \\
\hline Мы ездили $=$ & we went \\
\hline Мы работали $=$ & we worked \\
\hline Мы ходили $=$ & we went \\
\hline
\end{tabular}

Pre-test sentences

1. Мы ездили на работу. [We went to work.]

2. Мы ходили в университет. [We went to the university.]

3. Мы были в ресторане. [We were at the restaurant.]

4. Мы ездили в Аризону. [We went to Arizona.]

5. Мы ездили в Иркутск. [We went to Irkutsk.]

6. Мы ходили на озеро. [We went to the lake.] 
Processing Instruction and Russian: Further

7. Мы знаем, какое это кафе. [We know what kind of cafe that is.]

8. Мы знаем, какой это магазин. [We know what kind of store that is.]

9. Мы ездили в село. [We went to the village.]

10. Мы были в общежитии. [We were in the dormitory.]

11. Мы были в конторе. [We were in the office.]

12. Мы работали в консерватории. [We worked at the conservatory.]

13. Мы знаем, какая это аптека. [We know what kind of pharmacy that is.]

14. Мы были в бассейне. [We were at the pool.]

15. Мы работали в школе. [We worked at the school.]

Post-test sentences

1. Мы работали в селе. [We worked in the village.]

2. Мы были на озере. [We were at the lake.]

3. Мы ходили в школу. [We went to the school.]

4. Мы были в университете. [We were at the university.]

5. Мы знаем, какая это почта. [We know what kind of post office that is.]

6. Мы ходили в общежитие. [We went to the dormitory.]

7. Мы ездили в контору. [We went to the office.]

8. Мы знаем, какой это институт. [We know what kind of institute that is.]

9. Мы работали в Аризоне. [We worked in Arizona.]

10. Мы ходили в ресторан. [We went to a restaurant.]

11. Мы работали в Иркутске. [We worked in Irkutsk.]

12. Мы знаем, какое это кино. [We know what kind of movie theatre that is.]

13. Мы были на работе. [We were at work.] 
Processing Instruction and Russian: Further

14. Мы ходили в бассейн. [We went to the pool.]

15. Мы ходили в консерваторию. [We went to the conservatory.] 
Processing Instruction and Russian: Further

Appendix C.

Table 6. Vocabulary items used in PI and TI treatments, with an indication of their declensional classes and their frequencies in the treatment materials.

\begin{tabular}{|c|c|c|c|c|}
\hline Russian & English & $\begin{array}{c}\text { Declension } \\
\text { class }\end{array}$ & $\begin{array}{c}\text { Number of } \\
\text { occurrences } \\
\text { in PI } \\
\text { materials }\end{array}$ & $\begin{array}{c}\text { Number of } \\
\text { occurrences } \\
\text { in TI } \\
\text { materials }\end{array}$ \\
\hline Англия & England & 6 & 1 & 1 \\
\hline аптека & pharmacy & 4 & 6 & 6 \\
\hline Аризона & Arizona & 4 & 0 & 0 \\
\hline банк & bank & 1 & 4 & 5 \\
\hline бассейн & pool & 1 & 0 & 0 \\
\hline библиотека & library & 4 & 6 & 7 \\
\hline Вашингтон & Washington & 1 & 2 & 2 \\
\hline Воронеж & Voronezh & 1 & 1 & 1 \\
\hline Денвер & Denver & 1 & 1 & 1 \\
\hline дискотека & disco & 4 & 1 & 1 \\
\hline занятия & class & $\mathrm{n} / \mathrm{a}$ & 5 & 5 \\
\hline институт & institute & 1 & 5 & 3 \\
\hline Иркутск & Irkutsk & & 0 & 0 \\
\hline Калифорния & California & 6 & 2 & 2 \\
\hline Канада & Canada & 4 & 1 & 2 \\
\hline
\end{tabular}


Processing Instruction and Russian: Further

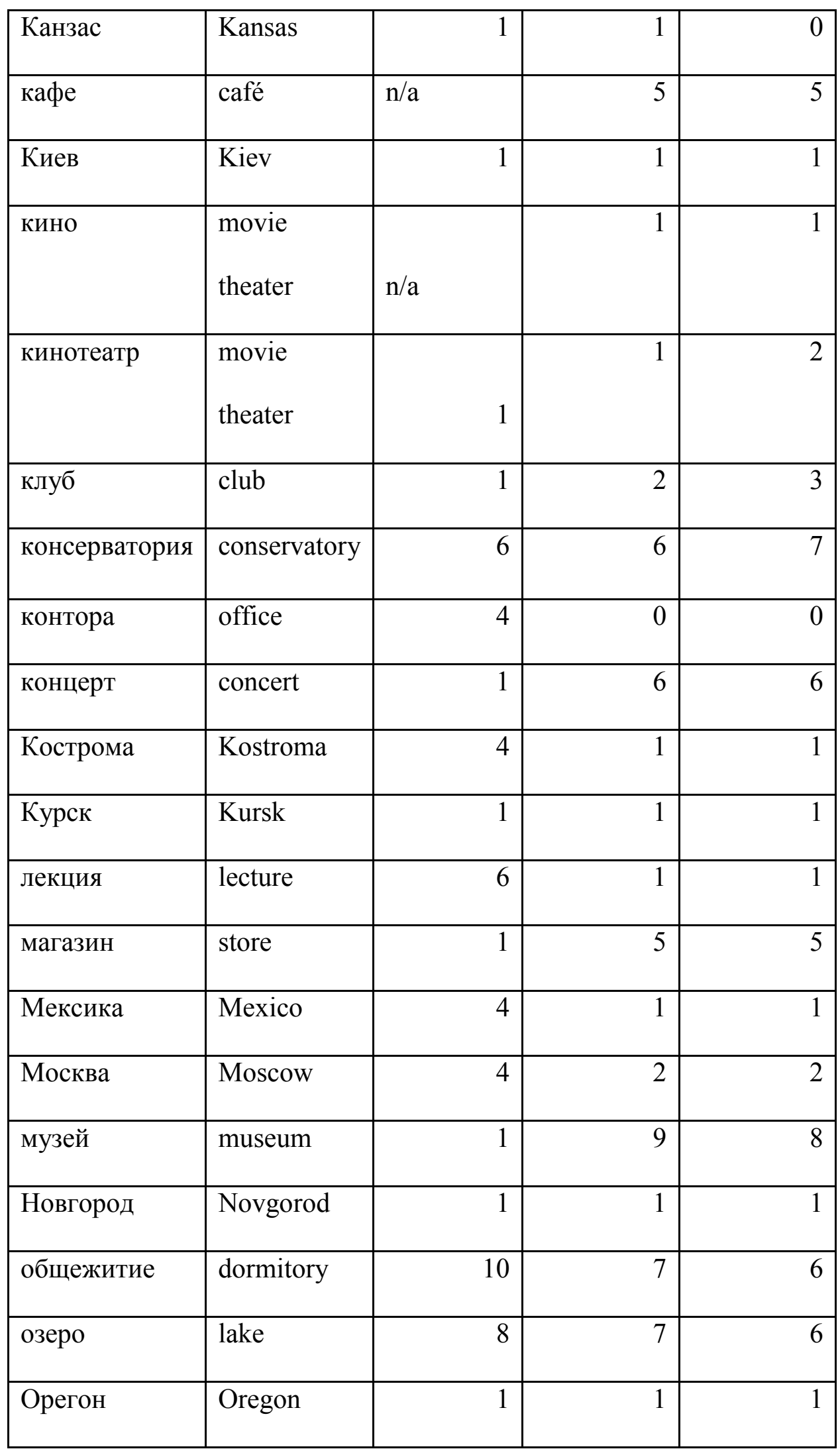


Processing Instruction and Russian: Further

\begin{tabular}{|c|c|c|c|c|}
\hline парк & park & 1 & 5 & 6 \\
\hline почта & post office & 4 & 4 & 4 \\
\hline Псков & Pskov & 1 & 1 & 1 \\
\hline работа & work & 4 & 6 & 7 \\
\hline ресторан & restaurant & 1 & 8 & 6 \\
\hline Россия & Russia & 6 & 4 & 4 \\
\hline Саратов & Saratov & 1 & 1 & 1 \\
\hline село & village & 8 & 0 & 0 \\
\hline Смоленск & Smolensk & 1 & 1 & 1 \\
\hline спортзал & gym & 1 & 6 & 6 \\
\hline стадион & stadium & 1 & 6 & 6 \\
\hline театр & theater & 1 & 2 & 1 \\
\hline Texac & Texas & 1 & 1 & 1 \\
\hline Топика & Topeka & 4 & 2 & 2 \\
\hline Тула & Tula & 4 & 1 & 1 \\
\hline университет & university & 1 & 6 & 6 \\
\hline Уфа & Ufa & 4 & 1 & 1 \\
\hline Флорида & Florida & 4 & 1 & 1 \\
\hline Франция & France & 6 & 3 & 4 \\
\hline школа & school & 4 & 8 & 8 \\
\hline Япония & Japan & 6 & 1 & 1 \\
\hline Total & & & 162 & 162 \\
\hline
\end{tabular}


Processing Instruction and Russian: Further

APPENDIX D. Sample tasks from the TI treatment

Activity 3. Make sentences from the cues below to tell where Sergei went to last week.

Remember: to indicate direction, you will need to put the word in the accusative case.

Серге́й ходи́л (went) в университе́т (and 12 more nouns)

[Sergei went to university]

Activity 4. Making sentences. Using one item from each column, make as many grammatically correct sentences as you can from these words.

\begin{tabular}{|c|c|c|}
\hline мой оте́ц ходи́л & \\
[my father went] & в [to] & апте́ка [pharmacy] \\
моя́ сестра́ ходи́ла & библиоте́ка [library] \\
[my sister went] & на [to] & and 16 more nouns \\
For males: я ходи́л & & \\
[I went] & & \\
For females: я ходи́ла & & \\
[Iwent] & & \\
\hline
\end{tabular}

Day 2.

Activity 3. The questions on the left ask if a person is headed to (идёт) to a place (destination in the accusative case). Disagree and state that the person is already (уже) at that place (location in the prepositional case). The first sentence has been done for you. 
Processing Instruction and Russian: Further

Ма́ма идёт в апте́ку?

Is momma going to the pharmacy? $\rightarrow$ Нет, она́ уже́ в апте́ке.

No, she is already at the pharmacy.

Activity 5. Work in pairs. You have to do the odd numbers, while your partner will check your answers. When your partner does the even numbers, you check the answers.

The sentences in the left hand column tell where people were. Transform them into sentences that tell where people went to.

For example:

Mark was in Kursk. $\rightarrow$ Mark went to Kursk.

Марк был в Ку́рске. $\rightarrow$ Марк е́здил в

Activity 6. The exclamations in the left hand column cause you to wonder when the speaker has ever been (ходи́л) to the place mentioned. Complete the responses with the directional form of the words cued in the exclamations.

Model: $\quad$ Кака́я там больша́я библиоте́ка! $\rightarrow$ Когда́ ты ходи́л в библиоте́ку?

[What a big library there is there. When did you go to the library?] 
Processing Instruction and Russian: Further

Appendix E. Sample tasks from the PI treatment

Activity 2a. You will hear a series of statements about what destinations your regular classroom teacher might have gone to in the past week. Listen to the sentences and based on what you know of your teacher, decide whether the statement tells of a place he/she definitely went to (да), a likely destination (наве́рно) or an unlikely destination (наве́рно нет).

\begin{tabular}{|l|c|c|c|}
\hline & $\begin{array}{c}\text { Да } \\
{[\text { Yes }]}\end{array}$ & $\begin{array}{c}\text { Наве́рно } \\
{[\text { Probably }]}\end{array}$ & $\begin{array}{c}\text { Наве́рно нет } \\
{[\text { Probably not }]}\end{array}$ \\
\hline 1. & $\square$ & $\square$ & $\square$ \\
\hline \multicolumn{3}{|c|}{ total of 10 sentences } \\
\hline
\end{tabular}

2b. Now you will hear what destinations your teacher has actually gone to in the past week. Circle the number for each. How many did you guess correctly?

Activity 3a. What destinations have you gone to in the past week? Circle all the sentences that are true for you.

\begin{tabular}{|l|l|}
\hline Male students read from this column & Female students read from this column \\
\hline $\begin{array}{l}\text { 1. Я ходи́л (have gone) в спортза́л. } \\
\text { [I went to the gym.] }\end{array}$ & $\begin{array}{l}\text { 1. Я ходи́ла (have gone) в спортза́л. } \\
\text { [I went to the gym.] }\end{array}$ \\
\hline and nine more sentences &
\end{tabular}


Activity 3b. Compare your answers with a classmate, by reading the sentences that you circled aloud to your partner.

As you listen to your partner, respond «Я то́же» if you have the same answer as your partner.

Give yourself a point for every answer you have in common with your partner.

Activity 4c. Where have people in your family traveled (е́здили) to? Match the sentence starts in the left column with actual places that people in your family have gone to.

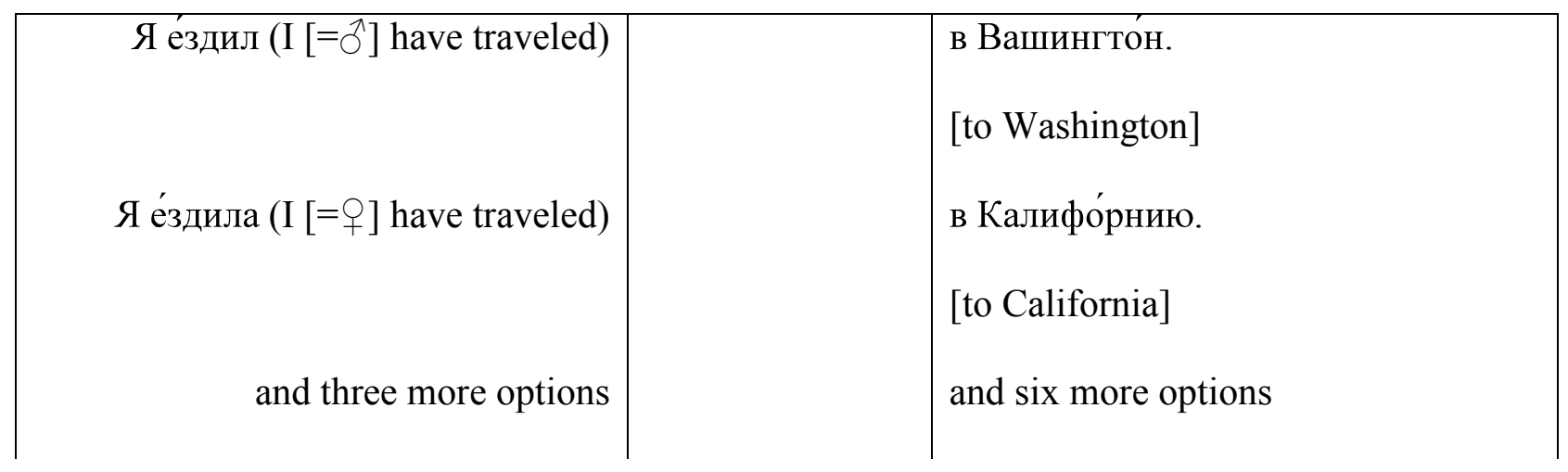

Day 2

Activity 2. As you listen and watch the next part of the presentation, you will see on each slide a pair of images. Note which form of the word is used as a destination, and which one is used as a location. Write in $D=$ destination or $L=$ location before each form of the word.

1. __ _ парк [park - accusative]

2. ___ _ шко́ле [school - prepositional] and six more pairs 
Activity 4. Джим [Jim] recently got a cell phone and he likes to call his friends and let them know where he is and where he is going. Look at the list of things he said, and indicate for each whether he is telling his friends where he is headed (destination with the accusative case) or where he is already (location with the prepositional case).

\begin{tabular}{|l|l|l|}
\hline Джим говори́т: [Jim says] & $\begin{array}{l}\text { On his way / } \\
\text { where he is going }\end{array}$ & $\begin{array}{l}\text { Is already there / } \\
\text { where he is }\end{array}$ \\
\hline $\begin{array}{l}\text { 1. Я сейча́с в университе́те. } \\
\text { [I am now at the university.] }\end{array}$ & & \\
\hline $\begin{array}{l}\text { 2. Я сего́дня на стадио́н. } \\
\text { [I'm headed to the stadium today.] }\end{array}$ & & \\
\hline and eight more sentences & & \\
\hline
\end{tabular}

Activity 6. John and Olga like to travel, and they are describing where they were or where they went to this past summer. Pay attention to the place phrase to decide whether it expresses location (prepositional case) or destination (accusative case). Complete each sentence with Мы были (=We were) if they are talking about a location

OR Мы е́здили (=We traveled to) if they are talking about a destination.

1. в Росси́и.

$[1$. in Russia.] and 10 more sentences. 
Processing Instruction and Russian: Further

Activity $6 \mathrm{~b}$. Compare your activities from last summer with John and Olga's. Circle all the sentences for which sentences could you say: Я то́же. 